\title{
Anthocyanin and Chlorophyll Content in Flush as Selection Markers on Fine Flavor Cocoa (Theobroma cacao L.)
}

\author{
Indah Anita-Sari ${ }^{1,2^{*}}$, Sobir ${ }^{2)}$, Irvan Faizal ${ }^{3)}$, Agung Wahyu Susilo ${ }^{1)}$, \\ Marcelinus A.S. Adhiwibawa ${ }^{4}$, and R.A.P. Nugroho ${ }^{2}$ \\ ${ }^{1}$ Indonesian Coffee and Cocoa Research Institute, Jl. PB. Sudirman 90, Jember, Indonesia \\ ${ }^{2)}$ Bogor Agriculture University, Jl. Meranti, Kampus IPB Dramaga, Bogor, Indonesia \\ ${ }^{3)}$ Agency for Assessment and Implementation of Technology, Jl. Raya Puspitek Serpong, Tangerang Selatan, Indonesia \\ ${ }^{4}$ Ma Chung University, Jl. Villa PuncakTidar No-01, Malang, Indonesia \\ Corresponding Author: indah.sari83@yahoo.com \\ Received: 15 October 2016/ Accepted: 6 November 2016
}

\begin{abstract}
Level of anthocyanin content in flush is different between fine flavor cocoa and bulk cocoa. This study was aimed to determine the potential of anthocyanin and chlorophyll content in flush as one of the selection indicator for fine flavor cocoa. Flush sampling was carried out at Cocoa Germplasm Collections in Kaliwining Experimental Station, Indonesian Coffee and Cocoa Research Institute, while anthocyanin and chlorophyll analysis was conducted at Laboratory of Ma Chung Research Center for Photosynthetic Pigments, Ma Chung University, Malang.The research utilized a completely randomized design consisted of four genotypes of fine flavor cocoa, namely DR 2, ICCRI 02, DRC 16, PNT 16 and five genotypes of bulk cocoa, namely Sulawesi 1, MCC 01, MCC 02, KW 617 and PA 191.Each treatment was repeated three times. Anthocyanin and chlorophyll content in flush was measured. Anthocyanin analysis was done by destructive methods, while flush color was observed based on Munsell Color Chart for Plant Tissues Data analysis used orthogonal contrast, multivariate and simple correlation. The results showed that there were differences in flush color on fine flavor cocoa and that of bulk cocoa. The flush of the fine flavor cocoa had a tendency towards yellow and that of bulk cocoa had a tendency toward red with different levels of variation among genotypes. The analysis results of chlorophyll content in flush showed that chlorophyll content of fine flavor cocoa was higher than bulk cocoa with a range of 2376-3692 $\mu \mathrm{mol} / \mathrm{L}$ for fine flavor cocoa and 1567-2628 $\mu \mathrm{mol} / \mathrm{L}$ for bulk cocoa. On the contrary, anthocyanin content in fine flavor cocoa was lower than bulk cocoa with a range of 3.82-5.72 $\mu \mathrm{mol} / \mathrm{L}$ for fine flavor cocoa and 6.01-11.88 $\mu \mathrm{mol} / \mathrm{L}$ for bulk cocoa. The analysis results of orthogonal contrasts showed that chlorophyll content value was more stable than anthocyanin. There was negative relationship between anthocyanin and chlorophyll in flush with the regression $\mathrm{Y}=-221,1 \mathrm{X}+3935$ with a value of correlation $\mathrm{r}=-0.50$. The anthocyanin and chlorophyll content in flush had a potential to be used as selection markers for fine flavor cocoa hybrid.
\end{abstract}

Keywords: anthocyanin, chlorophyll, flush, selection markers, Theobromacacao L. 


\section{INTRODUCTION}

A fine-flavor cocoa or better known as Java Cocoa is one of Indonesian specialty which has successfully entered world cocoa market. This type of cocoa has been planted in Indonesia since 1888 (van der Knaap, 1953 cit. Mawardi, 1982) and has been known as Java Criollo (Mawardi, 1982). This particular cocoa has unique character with its distinctive flavor and is generally better than bulk cocoa. Java Cocoa's distinctive feature is its white bean color, while fresh bulk cocoa bean possesses purple color (Anita-Sari et al., 2014). Fine-flavor cocoa and bulk cocoa demand continues to increase each year. High demand of cocoa is related to the importance of maintaining chocolate products quality, especially in terms of flavor (Daniel et al., 2012). This provides an opportunity for Indonesia to be able to continue increasing Fine-flavor cocoa production. However, production has decreased lately, one of which is caused by vascular streak dieback (VSD) disease.

Efforts to increase fine-flavor cocoa production is still continuing, but an obstacle encountered in the effort of assembling new planting material due to the lack of fineflavor cocoa genetic resources which is under extinction threat (Anita-Sari et al., 2014). Enriching genetic resources is the key factor in the breeding of the fine-flavor cocoa. The process of assembling the fine-flavor cocoa planting materials, in addition to genetic diversity requires a long periods of time. It is caused by the time spent waiting for cocoa plant to produce fruit before researcher could determine its seeds color. According to Sukartini \& Shah (2009), another obstacle encountered is the amount of time required for selection process which is done during regenerative phase. Before making selections of characters which will be encountered at generative phase, it is required to look for criterias used to select breeds early.
Fine-flavor cocoa selection methods have been developed since 1997 through the identification of flower colors and its influence on seed color (Winarno \& Iswanto, 1997). However in its development, the theory was disproved because they discovered some flowers of bulk cocoa germplasm did not contain anthocyanin. On the other hand, fine-flavor cocoa flowers contain anthocyanin. Results of other studies (Adhiwibawa et al., 2015) stated that of fine-flavor cocoa flush pigment reflectance differs from other cocoa. Anthocyanin level which is indicated by red pigment reflectance on bulk cocoa proved to be higher than that of fine-flavor cocoa. The results are consistent with the results of Anita-Sari et al. (2016) research which stated that anthocyanin content in fine-flavor cocoa flush is different with bulk cocoa. Fine-flavor cocoa anthocyanin content is relatively low compared to bulk cocoa. Research on other commodities exhibits anthocyanin pigment content in one of the organs will affect anthocyanin content in other organs. Anthocyanin is one of phenolic pigments which are expressed as red, blue (Lee \& Kevin, 2002) and purple color (Close $\&$ Christopher, 2003). The pigments are located in the cell's vacuole and functions as antioxidants (Woodson cit. Sukartini \& Shah, 2009). Anthocyanin content of cocoa plant can be found in the leaves, flowers, fruits and seeds (Anita-Sari et al., 2015). According to Gould \& Quinn (1996), anthocyanin found in cell palisade and mesophyll cork. Anthocyanin synthesis occurs during the growth of leaves (Woodall \& Stewart, 1998), during senesence (Field et al., 2001) and when plants respond to abiotic stresses (Close et al., 2000).

Results of related studies mention that anthocyanin formation in plant parts can occur simultaneously with chlorophyll formation. It is formed in quantity should the plant color is green. Therefore it indicates that 
plant part contains less anthocyanin compared to chlorophyll (Drumm-Herrel \& Mohr cit. Sukartini \& Shah, 2009). Anthocyanin formation is inhibited by chrolophyl formation (Woodall \& Stewart, 1998). Stabilization of the selection criteria needs to be done to establish appropriate selection method to enable early selection process. Early selection method on assembling fine-flavor cocoa planting material is very useful, especially for fine-flavor cocoa and non-fine-flavor cocoa corssbreeds. It would enable selection through organs other than flower such as fruit and seed. Accelerating selection process through certain criteria is particularly useful to increase genetic diversity of fine-flavor cocoa through crossbreeding. The purpose of this research is to find characters other than seed color to be used in selection method. It is done in order to enable early selection on fine-flavor cocoa.

\section{MATERIALS AND METHODS}

The study was conducted in March to August 2016. Sampling process was conducted in Cocoa Germplasm Colecction Garden of Kaliwining Experimental, Indonesian Coffee and Cocoa Research Institute, Jember. Anthocyanin and chlorophyll analysis was conducted at Ma Chung Research Center Laboratory for Photosynthetic Pigments, Universitas Ma Chung, Malang, East Java Indonesia. The experiment was conducted in a laboratory scale using a completely randomized design with three repetitions. Each repetition consisted of five flush samples taken from plants in the field randomly. Five flush samples were taken from each of fifteen (15) plants of each genotype. Flush samples were put into the ice-filled cooler to be transferred to Ma Chung Research Center Laboratory for Photosynthetic Pigments. Table 1 presented the four accessions of fine-flavor cocoa and five accessions of bulk cocoa used in this research.

The parameters measured were anthocyanin and chlorophyll flush content of each genotype. Anthocyanin and chlorophyll content were analyzed using destructive methods referring to Sims \& Gamon (2002) and Porra (2002). Color analysis was conducted based on Munsell Color Chart (Wilde, 2004) by matching flush color on each genotype with color on Munsell Color Chart. Data analysis was performed by calculating average concentration of anthocyanins and chlorophyll in each genotype tested. Variance analysis was conducted using orthogonal contrast analysis using SAS 9.1 program. Cluster analysis was conducted by utilizing multivariate-cluster analysis in STAR statistical program.

\section{RESULTS AND DISCUSSION}

Anthocyanin and chlorophyll content in four fine-flavor cocoa or Java Cacao genotypes flush was significantly different from that of the five non-fine-flavor cocoa genotypes (bulk). Chlorophyll content in the

Table 1. Fine-flavor cocoa and bulk cocoa genotypes for anthocyanin and chlorophyll study

\begin{tabular}{ll}
\hline Genotype & \multicolumn{1}{c}{ Information } \\
\hline Sulawesi 01 & Bulk cocoa, exploration result in East Kalimantan Province \\
MCC 01 & Bulk cocoa, exploration result in South Sulawesi Province \\
MCC 02 & Bulk cocoa, exploration result in South Sulawesi Province \\
PA 191 & Bulk cocoa, clone of Upper Amazon Forastero from Parinari \\
KW 617 & Bulk cocoa, selection result of Sulawesi 01 x TSH 858 crossbreeding \\
DR 2 & Fine-flavor cocoa result in Djati Roenggo \\
ICCRI 02 & Fine-flavor cocoa, exploration result in Penataran, East Java \\
DRC 16 & Fine-flavor cocoa, selection result of DR 53's line from Djati Roenggo \\
PNT 16 & Fine-flavor cocoa, exploration result in East Java \\
\hline
\end{tabular}


Table 2, Variance analysis of chlorophyl and anthocyanin content of fine- flavor cocoa and bulk cocoa genotypes

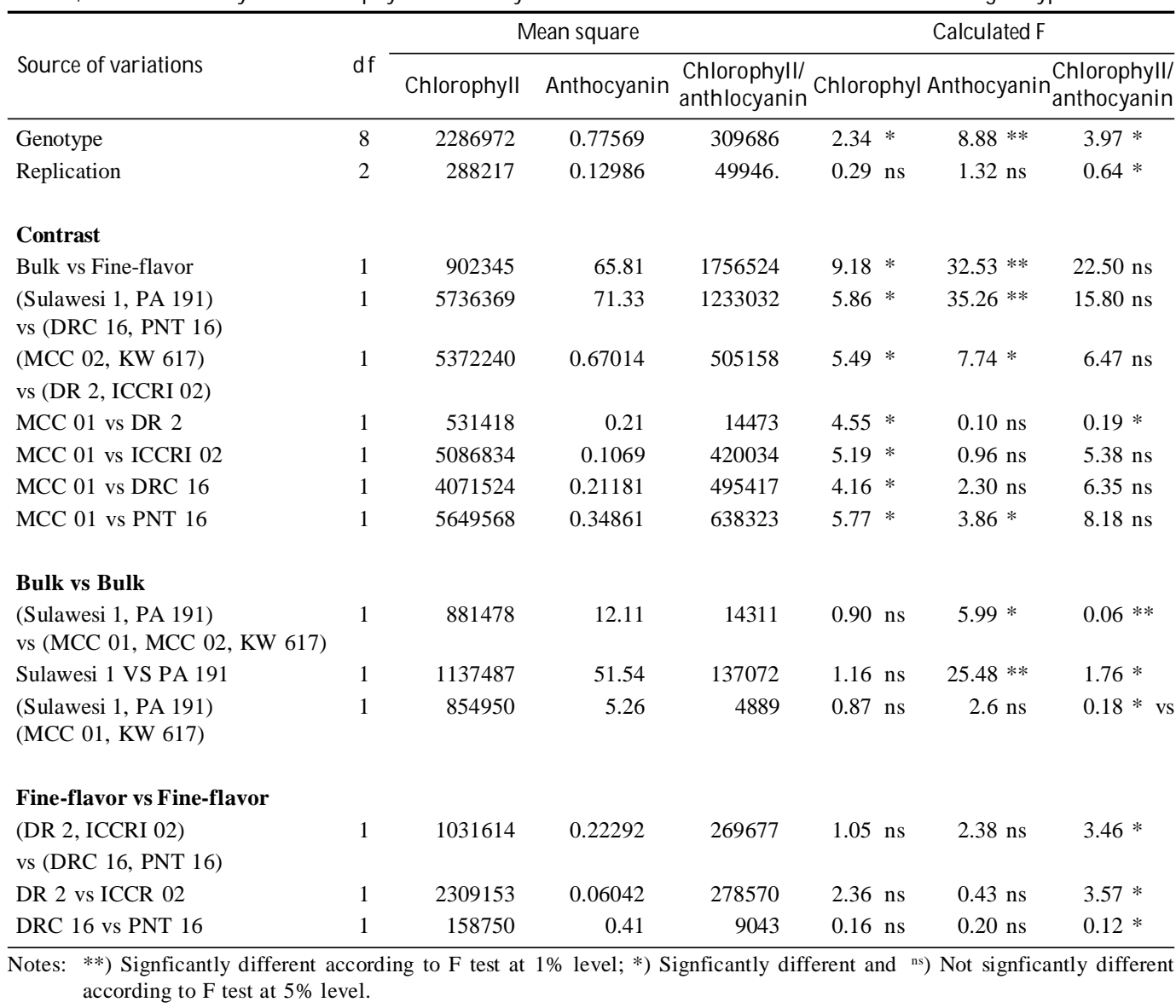

cross genotype fine-flavor cocoa's did not show significant differences, as well as bulk cocoa cross genotype. However, flush anthocyanin content exhibited variations for anthocyanin content in bulk cocoa flush. Fineflavor cocoa flush anthocyanin content was significantly different compared to bulk cocoa (Table 2). These results concur with Adhiwibawa et al. (2015) and Anita-Sari et al. (2016) researches which found that anthocyanin content in fine-flavor cocoa flush has different patterns tendency compared to bulk cocoa. Anthocyanin content in fine-flavor cocoa flush was lower compared to bulk cocoa, either through color reflectance analysis (Adhiwibawa et al., 2015) or destructive analysis.

The analysis of chlorophyll content of cross-fine-flavor cocoa did not show significant differences, as well as cross bulk cocoa. On the other hand, anthocyanin content in cross bulk cocoa exhibitted significant differences (Table 2). Cross bulk cocoa anthocyanin content variance exhibits that anthocyanin content could not be used as indicator for fine-flavor cocoa early selection due to its characteristic instability among tested cocoa groups. While chlorophyll content showed good stability in cross fine-flavor cocoa and cross bulk cocoa respectively, it was not significantly different in fine-flavor cocoa and bulk cocoa groups. It has a tendency to be more stable. Thus, flush chrorophyll content can be used as one of fine-flavor cocoa early selection criteria.

Anthocyanin and chlorophyll content ratio in flush did not exhibit good stability in both 
types of tested cocoa. Contrast analysis result exhibited significant differences on chlorophyll and anthocyanin ratio parameter for bulk cocoa and fine-flavor cocoa. Thus chlorophyll and anthocyanin ratio parameter can not be used as indicator for fine-flavor cocoa early selection process. These results correspond with Sims \& Gamon (2002) research result which stated that anthocyanins have a strong influence on chlorophyll; therefore anthocyanin has relatively no effect on chlorophyll content. Red/green ratio has a weak connection to anthocyanin and chlorophyll content. In contrast Gamon \& Surfus (1999) found that red/green ratio indicated good connection to anthocyanin and chlorophyll content. Gamon \& Sims (2002), stated that each species had red/green ratio, anthocyanin content and reflectation difference, even with chlorophyll absence depending on cell chemical environment.

The average value of the anthocyanin content in fine-flavor cocoa flush was lower than bulk cocoa with a range of 3.82-5.72 $\mu \mathrm{mol} / \mathrm{L}$ for fine-flavor cocoa and 6.01-11.88 $\mu \mathrm{mol} / \mathrm{L}$ for bulk cocoa. In contrast, fineflavor cocoa had higher average flush chrorophyll content compared to bulk cocoa with a range of $2376.47-3692.35 \mu \mathrm{mol} / \mathrm{L}$ for fine-flavor cocoa and bulk cocoa amounts to $1567.33-2627.91 \mu \mathrm{mol} / \mathrm{L}$ (Table 3). Different leaves color exhibits pigment content difference, especially chlorophyll and anthocyanin (Markham, 1988).
Bulk cocoa possess higher anthocyanin content in flush organ compared to fineflavor cocoa. The existence of positive connection for anthocyanin content in flush and seeds was researched in 'mango plant phenomenon' conducted by Sukartini \& Shah (2009) which states anthocyanin content in mango leaf have positive connection to anthocyanin content in mango fruit color. Anthocyanins are calculated based on cells mesocarp palisade exterior and mesophyll of darker leaves (Lightbourn et al., 2008). According to Lee \& Kevin (2002), anthocyanin phenolic pigment expressed as red, blue and purple color code (Close \& Christopher, 2003; Tanaka et al., 2008). The pigment exists in vacuole cell and function as antioxidants (Tanaka et al., 2008). According to Lightbourn et al. (2008), color is formed from several pigments, including chlorophyll, carotenoids, flavonoids and betalains. Betalains was divided into two classes, betaxanthins and betacyanins which produce yellow to orange or violet color (Harris et al., 2011). Flavonoids can be divided into colorless and color (anthocyanin). Chlorophyll is located at chloroplasts wichin cytoplasm cell. Carotenoid exists in kromatoplas while flavonoids and betalain are in vacuole cell.

Determining flush aside from utilizing destructive method is using Munsell color chart. Analysis result using Munsell color chart showd that fine-flavor cocoa possessed

Table 3. Average of chlorophyll and anthocyanin content on flush of fine-flavor cocoa and bulk cocoa

\begin{tabular}{lcc}
\hline Genotype & $\begin{array}{c}\text { Chlorophyll concentration }(\mu \mathrm{mol} / \mathrm{L}) \\
\text { Means } \pm \text { standard deviation }\end{array}$ & $\begin{array}{c}\text { Antocyanin concentration }(\mu \mathrm{mol} / \mathrm{L}) \\
\text { Means } \pm \text { standard deviation }\end{array}$ \\
\hline Sulawesi 01 & $1757 \pm 142$ & $11.88 \pm 1.15$ \\
PA 191 & $2628 \pm 61$ & $6.01 \pm 0.96$ \\
MCC 01 & $1776 \pm 46$ & $6.09 \pm 0.32$ \\
MCC 02 & $1567 \pm 130$ & $8.39 \pm 0.52$ \\
KW 617 & $1750 \pm 60$ & $6.85 \pm 0.98$ \\
DR 2 & $2376 \pm 78$ & $5.72 \pm 0.64$ \\
ICCRI 02 & $3617 \pm 288$ & $4.96 \pm 0.17$ \\
DRC 16 & $3423 \pm 161$ & $4.33 \pm 0.78$ \\
PNT 16 & $3692 \pm 277$ & $3.81 \pm 0.37$ \\
\hline
\end{tabular}


flush color tendency toward yellow color ( $\mathrm{Y}=$ yellow) with varying cross genotype intensity, unlike bulk cocoa which had tendency to red color $(\mathrm{R}=\mathrm{red})$ with varying cross genotype intensity (Figure 1). Flush color of the MCC 01 clones were included in bulk cocoa group in wich visually exhibited pale color, but it possessed a tendency toward red instead of yellow. Based on Munsell color chart analysis on both cocoa groups, there was good stability in flush color pattern. Fine-flavor cocoa possessed yellow color tendency $(\mathrm{Y})$, while bulk cocoa had red color tendency (R).

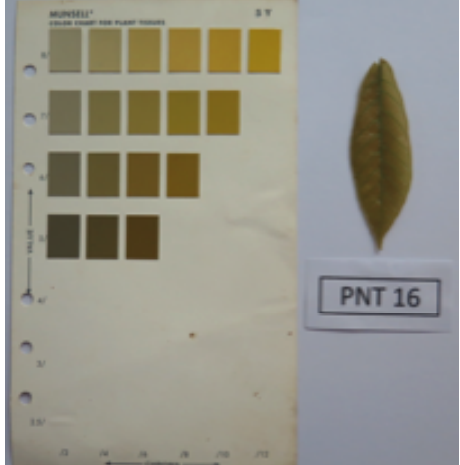

$(5 Y 7 / 8)$

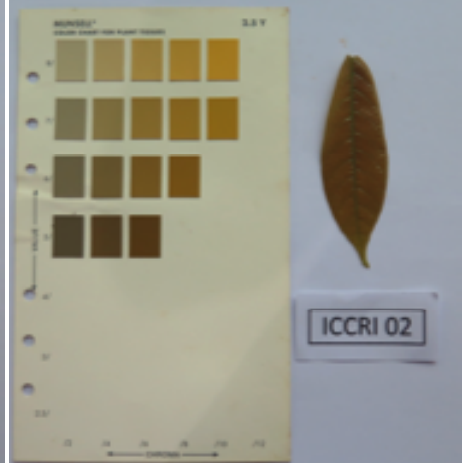

$(2,5 Y 6 / 8)$

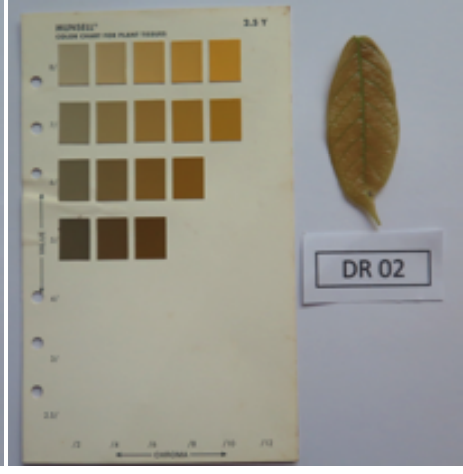

$(2,5 Y 6 / 6)$

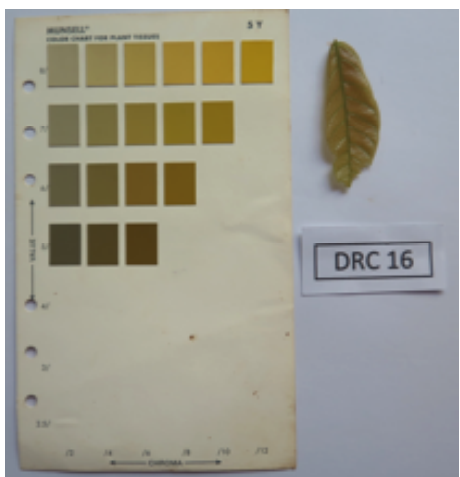

$(5 Y 7 / 8)$

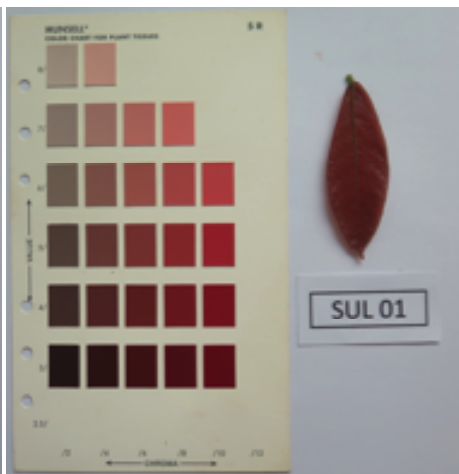

$(5 \mathrm{R} 3 / 10)$

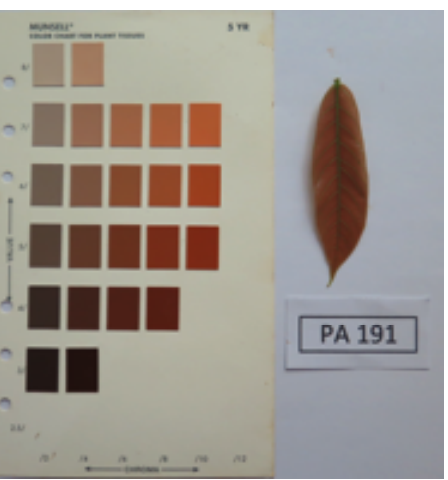

(5YR 5/10)

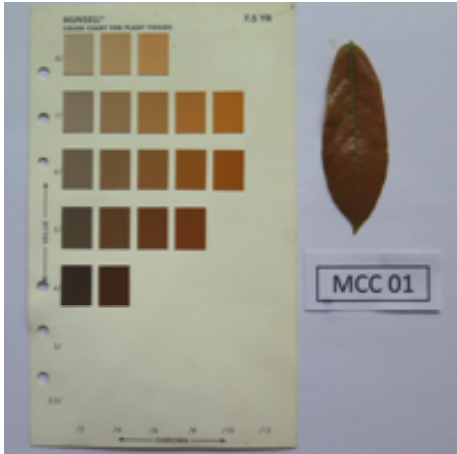

(5YR 5/6)

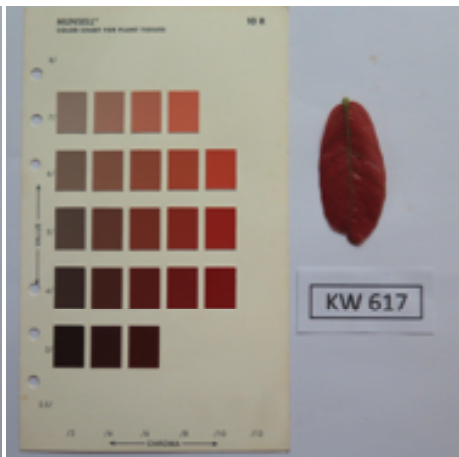

(10R 4/8)

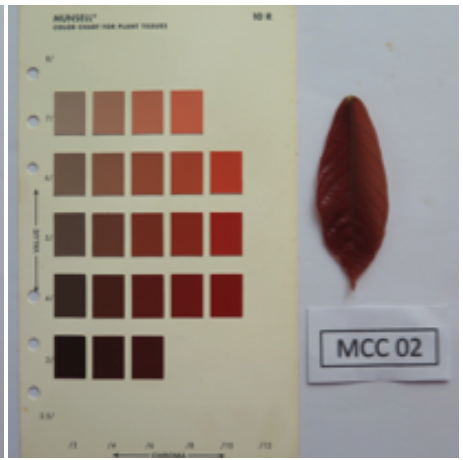

(10R 3/6)

Gambar 9. Variasi warna flush pada empat genotipe kakao mulia dan lima genotipe kakao lindak 
Anthocyanins normally exist in young leaves, roots and stems. Anthocyanins, especially those at leaf upper surface or in epidermal cells play a role in plant physiological processes (Jordheim, 2007). Anthocyanin synthesis occurs during leaves growth (Woodall et al., 1998). Anthocyanin biosynthesis started from cinnamic acid production of phenylalanine enzyme in shikimic acid cycle conducted by phenylalanine amoniliase enzyme (PAL) which then converted to fumaric acid and modified into malonil CoA. Anthocyanin biosynthesis is controlled by enzyme activity that in certain conditions can be affected by extreme environmental conditions (Woodall et al., 1998).

Leaf pigment is integrally associated to the leaf functions (Sims \& Gamon, 2002). Leaf color is indicated by three color combination namely compounds that produce green chlorophyll, carotenoids and flavonoids. They exhibit yellow and purple anthocyanins which show up as blue color. Young leaves or flush is dominated by anthocyanin content. Anthocyanins are more involved in the early stages of the leaf formation. It is caused by sugar content formed in plant before it could photosynthesize (Alkema \& Seagerl, 1982; Mlodzinska 2009).

Simple correlation analysis result exhibits that high levels of anthocyanin content associated with lower chlorophyll content in cocoa flush with regression equation $\mathrm{Y}=$ $-221.1 \mathrm{X}+3935$, and correlation $\mathrm{r}$ value $=$ -0.50 . Anthocyanin formation in plant can occur simultaneously with chlorophyll formation in quantity should a plant is green in color, therefore that section contains less anthocyanin compared to chlorophyll (Drumm-Herrel \& Mohr cit. Sukartini \& Shah, 2009) Anthocyanin formation could be inhibited by the formation of chlorophyll (Woodall et al., 1998). Sims \& Gamon (2002) stated that there was an association between chlorophyll content with other formed colors.
There was a correlation between red/green ratio on anthocyanin and chlorophyll content in the leaves. Anthocyanin content depends on plant growing environment.

Cluster analysis result based on chlorophyll and anthocyanin characteristics shows separate grouping between fineflavor cocoa and bulk cocoa (Figure 3). In general, the pattern of chlorophyll and anthocyanin content distribution for fineflavor cocoa and bulk cocoa could be separated visually, destructively and non destructively. Related research results explained that anthocyanins play an important role in morphology indicator for plant selection process produced by crossbreeding (Wang, 2007; Dai et al., 2016). It can be used as indicator for pigmentation pattern and plant gene expression (Albert et al., 2014). There is a correlation between fruit and petal color. Cultivars with red fruit color will have dark red petals (Holland et al., 2009). There is stable pattern tendency between anthocyanin and chlorophyll content of fine-flavor cocoa and bulk cocoa flush. Both of these characters can be used as morphological indicators in selecting fineflavor cocoa especially those produced from crossbreeding.

The potency of anthocyanin and chlorophyll measurement in fine-flavor cocoa flush to be used as morphological indicators for selection criteria needs to be supported in molecular level. It is caused by the fact that anthocyanin and chlorophyll content is influenced by environmental conditions. Molecular analysis approach of genes controlling anthocyanin and chlorophyll in flush organ such as chloroplast genes are necessary to support the establishment of the selection criteria. Maturase $\mathrm{K}($ mat $\mathrm{K})$ gene is one of genes existing in chloroplast is regarded as the most accurate gene used to detect kinship of a species (Virgilio et al., 2012). Gene analysis of mat $\mathrm{K}$ is one approach to 
Anita-Sari et al.

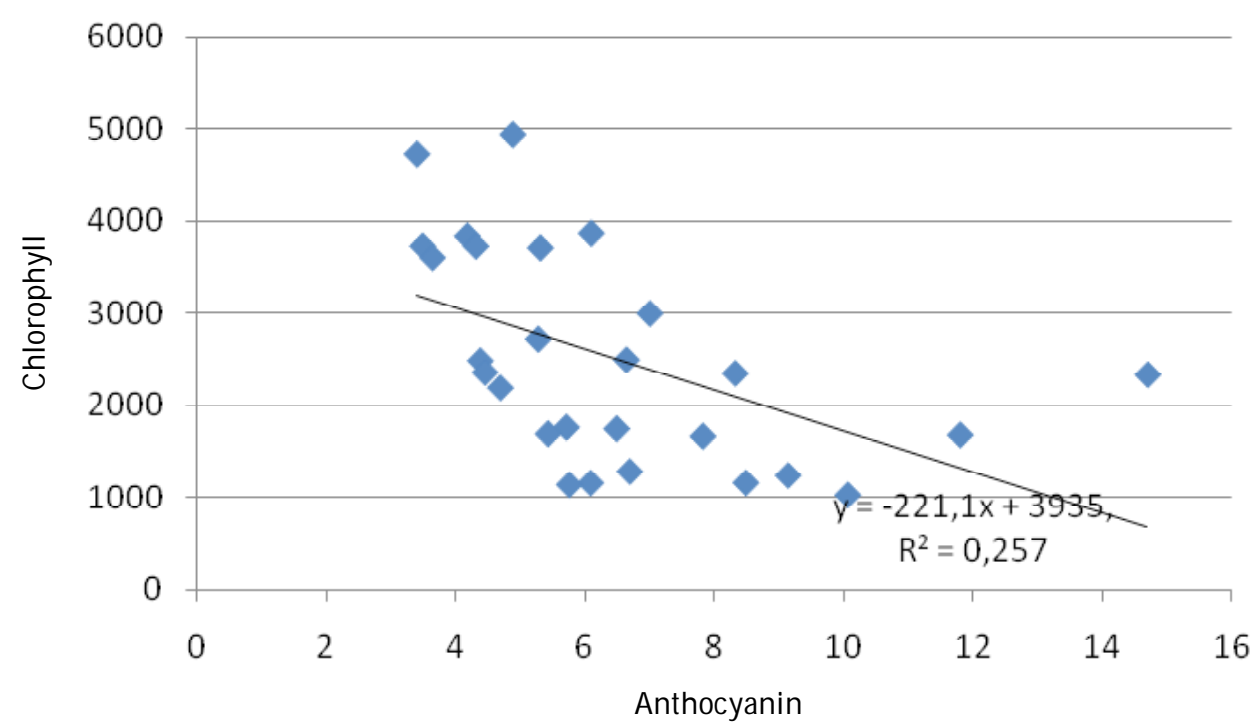

Figure 2. Relationship between chlorophyll and anthocyanin content in flushes of cocoa plants

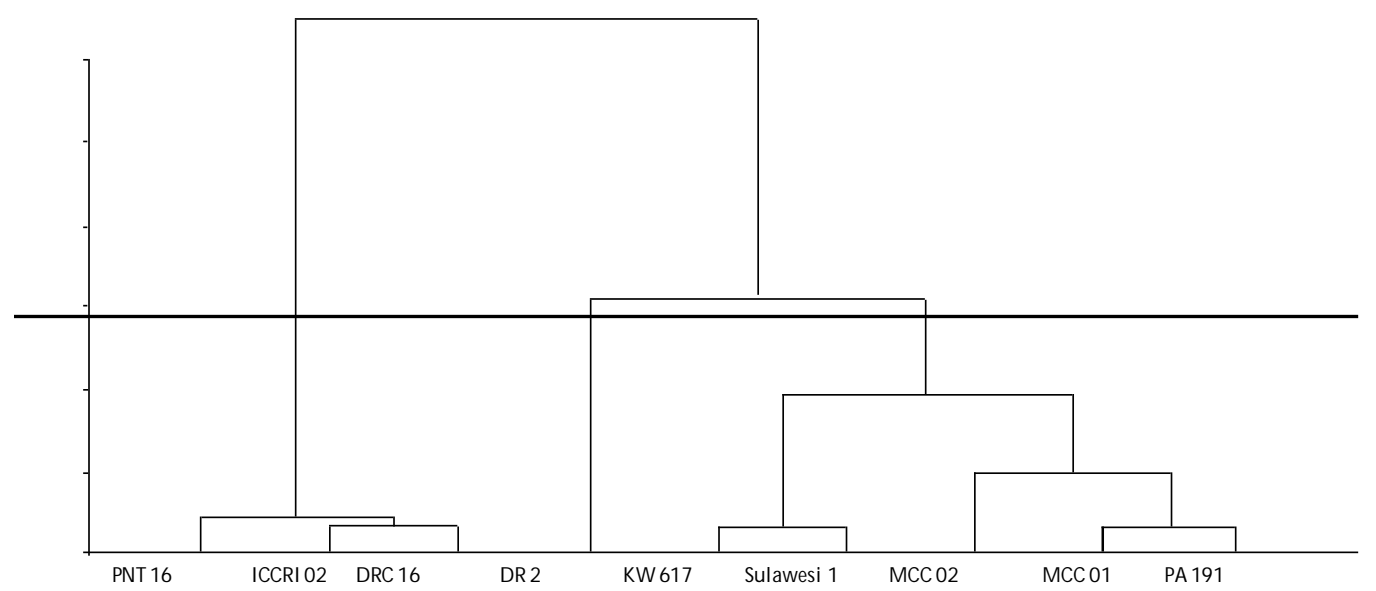

Figure 3. Dendogram of fine-flavor cocoa and bulk cocoa genotype based on anthocyanin and chlorophyll content 
find out anthocyanin and chlorophyll characteristics in fine-flavor cocoa and bulk cocoa flush organ without any environmental influences.

\section{CONCLUSION}

Chlorophyll content in fine-flavor cocoa flush is higher compared to bulk cocoa. On the other hand, anthocyanin content in bulk cocoa was higher than fine-flavor cocoa. Chlorophyll content showed good stability in both cocoa types therefore chlorophyll could be used as one of selection criteria with undetermined threshold intensity. Fine-flavor cocoa flush color had yellow color tendency $(\mathrm{Y}=$ yellow $)$ and bulk cocoa tended to possess red color $(\mathrm{R}=\mathrm{red})$ with different levels of variation among genotypes. Flush color characteristics can be used as an indicator of early selection for fine-flavor cocoa in seedling/vegetative stage.

\section{ACKNOWLEDGEMENT}

Authors extend their gratitude to Director of Indonesian Coffee and Cacao Research Institute for permission to conduct this research, also to technicians of Cacao Plant Breeding Laboratorium for their help during research process.

\section{REFERENCES}

Adhiwibawa, M.A.S.; I. Anita-Sari; K.R. Prilianti; A.W. Susilo; I.Limatara \& T.H.P Brotusudarmo (2015). Rapid determination of anthocyanin in cocoa (Theobroma cacao L.) leaves using digital image processing for fine cocoa clones selection. $10^{\text {th }}$ International Symposium on Modern and It,s Applications Indonesia. 10-13 August 2015.

Albert, N.; A.G. Griffiths; G.R. Cousins; I.M. Verry \& W.M. William (2014). Anthocyanin leaf markings are regulated by a family of R2R3-MYB genes in the genus Trifolium. New Pathologist, 205, 882-893.

Alkema, J. \& S.L. Seagerl (1982). The chemical pigments of plant. Journal of Chemical Education, 59, 183-186.

Anita-Sari, I.; A.W. Susilo; Yusianto \& S. Wardani (2012). Karakterisasi dan penentuan warna biji pada beberapa genotipe fineflavor cocoa (Theobroma cacao L) sebagai kriteria seleksi. Pelita Perkebunan, 28, 136-144.

Anita-Sari, I.; A.W. Susilo \& B. Setyawan (2016). Chromatographic identification of leaf color characteristics on (fineflavor and bulk cacao as selection indicator. Pelita Perkebunan, 32, 1-9.

Close, D.C.; C.L. Beadle; P.H. Brown \& G.K. Holz (2000). Cold-induced of photoinhibition affects establishment of Eucalyptus nitens (Deane and Maiden) Maiden and Eucalyptus globules Labill. Trees, $15,3241$.

Close, D.C. \& L.B. Christoper (2003), The ecophysiology of foliar anthocyanin. Botanical Review, 69, 149-161.

Dai, W.; T. Girdthai; M. Ketudat-Cairns; R. Tang; Z. Huang \& S. Wang (2016). Genetic analysis for anthocyanin and chlorophyll content in repeseed. Crop Protection, 46, 790-795.

Daniel, S., P. Laderach \& M. Paschall (2012). Reaching High Value Market: Fine Flavor Cocoa in Ghana. International Institute for Environment and Development. University of St. Gallen. Switzerland.

Field, T.S., D.N. Lee \& N.M. Holbrook (2001). Why leaves turn red in autumn: the role of anthocyanins in sensing leaves of red-osier dogwood. (Lancaster). Plant Physiology, 127, 566-574.

Gamon, J.A. \& J.S. Surfus (1999). Assessing leaf pigment content anf activity with a reflectometer. New Phytologist, 143, 105-117. 
Gould, K.S. \& B.D. Quinn (1996). Do anthocyanin protect leaves of New Zealand native species from UV-B. New Zealand Journal of Botany, 37, 175-178.

Harris, N.N.; J. Javellana.; K.M. Davies; P.E. Jameson; S.C. Deroles; K.E. Calcott; K.S. Gould \& K.E. Schwinn (2011). Betalain production is possible in anthocyanin-producing plant species given the presence of DOPAdioxygenase and L-DOPA. BMC Plant Biology, 12, 1-12.

Holland, D.; K. Hatib \& I. Bar-Ya'akov (2009). Pomegranate: Botany, Horticulture, Breeding. Horticulture Review, 35, 27-191.

Iswanto, A. \& H. Winarno (1997). Potential fineflavored cocoa clones to produce purple and necrotic beans. Pelita Perkebunan, 13, 1-7.

Jordheim, M. (2007). Isolation, Identification and Properties of Pyranoanthocyanins and Anthocyanin Forms. Disertation Department of Chemistry University of Bergen. Norwegia.

Lee, D.W. \& S.G. Kevin (2002). Why leaves tum red: pigments called anthocyanins probably protect leaves from light damage by direct shielding and by scavenging free radicals. American Science, 90, 1-6.

Lightbourn, G.J.; R.J. Griesbach, J.A. Novotny $\&$ B.A. Clevidence (2008). Effects of anthocyanin and carotenoid combinations on foliage and immature fruit color of Capsicum annuum L. Journal of Heredity, 99, 105-111.

Markham (1988). Cara Mengidentifikasi Flavonoid. Penerbit ITB, Bandung, Indonesia.

Mawardi, S. (1982). 1912-1981: Tujuh puluh tahun pemuliaan tanaman cokelat di Indonesia. Menara Perkebunan, 50, 17-22
Moldzinska, E. (2009). Survey of plant pigment: molecular and environmental determinants of plant color. Acta Biologica Cracoviensia, 51, 7-16.

Porra, R.J. (2002). The chequered history of the development and use of simultaneous equations for the accurate determination of chlorophylls a and b. Photosynthesis Research, 73, 149-156.

Sukartini \& M.J.A. Syah (2009). Potensi kandungan antosianin pada daun muda tanaman mangga sebagai kriteria seleksi dini zuriat mangga. Jurnal Hortikultura, 19, 23-27.

Sims, D.A. \& J.A. Gamon (2002). Relationships between leaf pigment content and spectral reflectance across a wide range of species, leaf structures and developmental stages. Remote Sensing of Environment, 81, 337-354.

Tanaka, Y.; N. Sasaka; \& A. Ohmiya (2008). Biosynthesis of plant pigments: Anthocyanins, betalains and carotenoids. The Plant Journal, 54, 733-749.

Virgilio, M.; K. Jordaens \& F. Breman (2012). Turning DNA barcodes into an alternative tool for identification: African fruit files as a model (poster). Consortium for the Barcode of Life (CBOL).

Wang, T.Q. (2007). Material breeding, heredity and utilization of purple-red leaf marker character in Brassica napus L. In: International Rapeseed Conference, $12,343-346$.

Woodall, G.S. \& G.R. Stewartl (1998). Do anthocyanins play a role in UV protection of the red juvenile leaves of Syzygium. Journal of Experimental Botany, 49, 1447-1450.

$$
* * 0 * *
$$

